\title{
Short-term effects of Theracurmin dose and exercise type on pain, walking ability, and muscle function in patients with knee osteoarthritis
}

\author{
Yun-A Shin ${ }^{1, *}$, Min-Hwa Suk ${ }^{2}$, Hee-Seung Jang ${ }^{1}$, Hye-Jung Choi ${ }^{3}$ \\ 'Department of Exercise Prescription \& Rehabilitation, Dankook University, Cheonan, Korea \\ ${ }^{2}$ Department of Physical and Rehabilitation Medicine, Samsung Medical Center, Seoul, Korea \\ ${ }^{3}$ Department of Counseling, Health, and Kinesiology, Texas A\&M University-San Antonio, San Antonio, TX, USA
}

The purpose of this study was to investigate the short-term of Theracurmin dose and exercise type on pain, walking ability, and muscle function in patients with knee osteoarthritis. Twenty-five patients with knee osteoarthritis randomly selected to Theracurmin intake (T) group and Theracurmin in combined with exercise $(T+E)$ group. T group $(n=13)$ was taken orally a capsule of $700 \mathrm{mg}, 3$ times per day, (total 2,100 $\mathrm{mg}, 35 \mathrm{mg} / \mathrm{kg}$-body weight). T+E group ( $\mathrm{n}=12)$ performed aerobic training of 30-min walking and weight training for increasing leg muscular strength. After treatment, the number of steps, muscle mass, range of motion of knee, and the muscle strength in flexion and extension significantly increased. The percent body fat, visual analogue scale, The Western Ontario and McMaster score, centers of pressure with closed eye, 10-m walking ability, stair ascending speed were significantly decreased after treatment. Although no difference observed between the $\mathrm{T}$ and $\mathrm{T}+\mathrm{E}$ groups, the 4-week intake of Theracurmin with and without exercise appeared to be effective in reducing the pain and enhancing muscular and balancing function. Therefore, Theracurmin intake for early symptoms and additional exercise as symptoms alleviate might be an effective way of delaying and managing osteoarthritis, and additional studies investigating the effects of Theracurmin and exercise on osteoarthritis could be beneficial.

Keywords: Theracurmin, Exercise, Pain, Walking ability, Knee osteoarthritis

\section{INTRODUCTION}

Osteoarthritis, also known as degenerative joint disease, gradually destroys the joints over time. The biochemical cause of osteoarthritis is still not entirely clear, but it has been reported that matrix metalloproteinases (MMPs) are involved in the degradation process of cartilage tissue. MMPs are excessively generated when the joint structure is abnormal or when an abnormally strong mechanical or biochemical stimulus acts on the articular cartilage tissue (Henrotin et al., 2002).

Osteoarthritis is more likely to occur with increasing age (Cross et al., 2014; Felson et al., 2000). Patients with osteoarthritis suffer from symptoms such as joint pain, decreased daily living function,

joint deterioration, and gait deviation (Franklin et al., 2008; Guccione et al., 1994). Osteoarthritis mainly causes pain due to loss and degeneration of cartilage tissue that functions to prevent friction and absorb impact (Davies et al., 2008). Loss and degeneration of cartilage tissue thus results in a decrease in walking speed and knee joint working range and limits daily living function. These changes eventually lead to diminished muscular strength and balance control from weakened muscles surrounding the knee joint (Hong, 2007). Therefore, rehabilitation treatment programs for osteoarthritis patients must be a combination of methods that decrease pain and stress on the joint and improve muscular function.

Most previous studies reported that aerobic exercises like walking and weight training (for strengthening the quadriceps femoris

${ }^{\star}$ Corresponding author: Yun-A Shin (10 https://orcid.org/0000-0002-8480-3454 Department of Exercise Prescription \& Rehabilitation, College of Sports Science, Dankook University, 119 Dandae-ro, Dongnam-gu, Cheonan 31116, Korea Tel: +82-41-550-3831, Fax: +82-41-550-3830, E-mail: shinagel@empas.com Received: August 7, 2017 / Accepted: December 5, 2017

This is an Open Access article distributed under the terms of the Creative Commons Attribution Non-Commercial License (http://creativecommons.org/licenses/by-nc/4.0/) which permits unrestricted non-commercial use, distribution, and reproduction in any medium, provided the original work is properly cited. 
muscle) are effective in decreasing pain and improving muscular function (Jordan et al., 2003; Roddy et al., 2005). Osteoarthritis is most common in the knee joint. Osteoarthritis involves inflammation and decreased function of not only the cartilage of the knee but also the muscles, tendons, ligaments, and synovia of the knee; therefore, it is challenging for osteoarthritis patients to perform the training treatment without pain management (Aigner et al., 2006).

Pain is caused by direct stimulation of pain receptors that triggers an inflammation mediator or by secondary inflammation from biochemical or autoimmune responses. Therefore, the most common treatment for decreasing the pain of osteoarthritis has been the administration of analgesic and nonsteroidal anti-inflammatory drugs. However, these drugs can cause severe gastrointestinal and cardiovascular adverse events with long-term use (Felson et al., 2000), and disease modifying agents that not only decrease the pain but also delay the progression of osteoarthritis would be beneficial.

Curcumin is a yellow polyphenolic spice extracted from rhizomes of curcuma long a linn, a plant classified as in the ginger family and mainly used for cooking foods like curries. Recently it has been shown to have anti-inflammatory and antioxidative properties according to many studies (Goel et al., 2008; Vogel and Pelletier, 1815). It reported that curcumin regulates biochemical molecular mechanisms by controlling various molecular targets such as transcription factors, cytokines, and enzymes (Gupta et al., 2012). These effects of curcumin are reported to be effective for diseases related to chronic inflammation such as cardiovascular disease, metabolic syndromes, osteoarthritis, and other aging related diseases (Goel et al., 2008; Gupta et al., 2012; Wongcharoen and Phrommintikul, 2009). Curcumin has also been reported to regulate osteoarthritis without any gastrointestinal adverse effects (Mobasheri et al., 2012).

Despite the many reports on the beneficial effects of curcumin, it has low bioavailability when taken orally and has a short halflife. Therefore, a limited number of studies shows effects of oral curcumin taken by human subjects. Accordingly, a drug called Theracurmin recently developed with the physiologic activity of curcumin increased by 27 times, and it was reported that the pain of osteoarthritis patients significantly decreased after taking Theracurmin for 8 weeks (Nakagawa et al., 2014). However, the studies on the effects of Theracurmin intake have yet to show consistent results of significantly decreased pain or other significant improvements (Akazawa et al., 2012; Mathy-Hartert et al., 2009; Nakagawa et al., 2014). In addition, although previous studies involving treatment with Curcumin have demonstrated positive effects in decreasing pain, there have been no studies demonstrating an increase in functional capability. A study needs to be done demonstrating the effects of curcumin in conjunction with exercise, which is the suggested rehabilitation treatment program for osteoarthritis patients.

Therefore, this study was to investigate the effects of Theracurmin (Kyungdong market, Seoul, Korea) intake for reducing pain in conjunction with rehabilitation training for osteoarthritis affects pain and muscular function of osteoarthritis patients.

\section{MATERIALS AND METHODS}

\section{Subjects}

Osteoarthritis patients with knee pain who visited Dream Hanmaum Rehabilitation Medicine located in Seoul, selected 25 patients satisfied the clinical and radiologic diagnostic criteria for knee joint osteoarthritis proposed by the Rheumatic Society (Altman, 1991), and also satisfied the criteria for second to third degree involvement on the Kellgren-Lawrence magnitude scale on more than one knee. The study was approved by the Institutional Ethnics Committee of Physical Education of the Dankook University (2015-05-001). Written informed consent obtained from all subjects. Patients with under drug treatment for other diseases, history of drug hypersensitivity reactions, and a swelling on their knee excluded from this study. All the selected patients were to provide informed consent before the start of the study. The final selected subjects randomly split into two groups (Theracurmin intake group, $\mathrm{T}$ group; Theracurmin with exercise group, $\mathrm{T}+\mathrm{E}$ group) (Table 1). In addition, because changes in physical activity can affect the treatment, all subjects given a step-measuring instrument so that they could record daily steps during the treatment period in addition to the exercise time. Changes in the number of steps described in Fig. 1. The number of steps during the treatment period significantly increased $(F=4.713, P<0.05)$, with a tendency of correlation effect between the treatment and

Table 1. Baseline demographic of the knee osteoarthritis patients according to the treatment

\begin{tabular}{lcccc}
\hline Variable & $T(n=13)$ & $T+E(n=12)$ & \multicolumn{2}{c}{ Sig } \\
\hline Age (yr) & $44.77 \pm 5.38$ & $40.58 \pm 7.71$ & -1.583 & 0.127 \\
Duration of knee pain (mo) & $3.31 \pm 1.18$ & $4.08 \pm 1.38$ & -1.191 & 0.246 \\
Site of knee & & & & \\
$\quad$ Right:left & $6: 7$ & $8: 4$ & & \\
Grade & $1.69 \pm 0.63$ & $1.41 \pm 0.52$ & 1.118 & 0.275
\end{tabular}

Values are presented as mean \pm standard deviation or number. $\mathrm{T}$, Theracurmin intake group; $T+E$, Theracurmin with exercise group. 


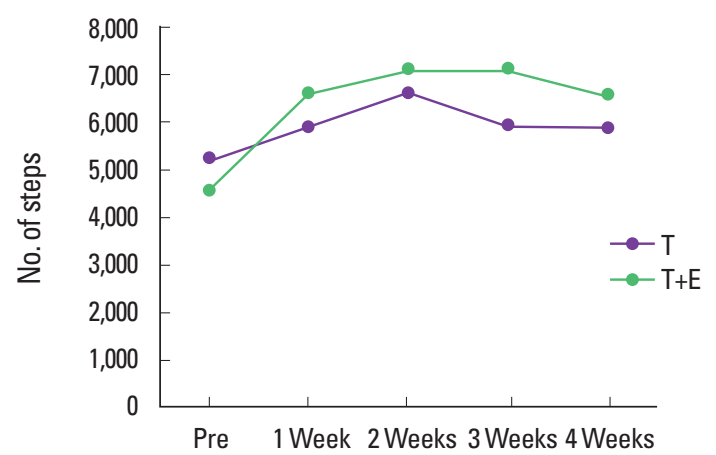

Fig. 1. The changes of steps during treatment. T, Theracurmin intake; $T+E$, Theracurmin with exercise.

the groups $(F=4.333, P=0.051)$, but there was no difference between the two groups.

\section{Body composition measurement}

Every subject underwent anthropometric examination while wearing light clothes; data regarding medical history also collected. Body weight (BW) and body fat percentage measured using InBody (Inbody 4.5, Biospace, Seoul, Korea), and body mass index (BMI) calculated as weight $(\mathrm{kg})$ divided by height $(\mathrm{m})$.

\section{Pain test}

Degree of pain for osteoarthritis patients was measured using a visual analogue scale (VAS), A translated contents of The Western Ontario and McMaster Universities Osteoarthritis index (WOMAC-VA3.0) verified by Yi et al. (2008) and Bellamy (1988) were used for this study. The survey included three major sections on pain, joint stiffness, and difficulty in physical function. The pain section had five questions, the joint stiffness section had two questions, and the difficulty in physical function section had 17 questions total. The questionnaire administered by a trained physical therapist after a face-to-face interview.

\section{Range of motion of knee test}

Knee joint flexion angle measured with the patient lying down on the examination table with the leg flexed and bent voluntarily as much as possible at both, the right and left knee using a goniometer. Knee joint extension angle measured with the patient lying with his/her face down on the examination table with a pillow underneath the thigh and the knee joint extended on both, the right and left knee using a goniometer.

\section{Balance test}

The balance test involved examining the patient's performance while standing on one leg under both conditions: centers of pressure (COP) with the eyes open and eyes closed, and the performance in the balance wobble test when standing. The durations for which the patient stood on one leg with the eyes open and eyes closed were measured in seconds, and the duration was considered till the time the lifted foot touched the ground or when the maintaining foot moved more than twice. The balance wobble test applied while standing used to analyze the degree to which the patient's balance shook, in millimeters, when he/she stood on the balance disk and when he/she stood on one leg.

\section{Walking ability test}

The 10-m walking test and going up and down stairs that are similar to the daily activity of osteoarthritis patients performed as walking ability test. The 10-m walking test measured as the time in seconds that the subjects wearing comfortable shoes took to walk $10 \mathrm{~m}$ as fast as possible after the "start" sign. In addition, a ground reaction plate installed on the $10 \mathrm{~m}$ straight course for measuring the weight loaded on the pelvis. Walking up and down stairs measured as the time in seconds the subjects took when walking up and down 10 stairs of $1.6-\mathrm{cm}$ height in a row without running.

\section{Isokinetic strength test}

Peak torque, total work, and average power of thigh measured using an isokinetic training instrument called Biodex (Biodex B-2000, Biodex Medical Systems Inc., Shirley, NY, USA). Subjects were performed the procedure by repeating the warm-up exercise five times so that they could exhibit their maximum capacity. Gravity effect torque measured and analyzed to rule out the effect coming from the weight of the leg. Subjects sat on a flat chair seat, placed the knee joint axis parallel to the dynamometer axis, and fixed their upper body with a torso belt and seat belt to minimize interference except for the quadriceps femoris muscle. The test repeated 5 times at $60^{\circ} / \mathrm{sec}$ to measure the maximum muscular strength and the total work amount, and the subjects were encouraged to demonstrate their maximum ability.

\section{Curcumin intake method}

Curcumin intake was recommended to be ingested within the approved range of dosage by the Food and Drug Administration as "Generally Regarded As Safe" (0.1-3 mg/kg-BW, clinical development plan) (Chemoprevention Branch and Agent Development Committee, 1996). However, preliminary studies and dis- 
cussions suggested that this dosage might be too low for physiologic activity due to low intestinal absorption and short half-life of curcumin (Anand et al., 2007; Shoba et al., 1998). Other studies suggested a dosage of up to $12 \mathrm{~g} /$ day is safe for humans (Anand et al., 2007), with no side effects when $180 \mathrm{mg}$ of Theracurmin was taken per day for 8 weeks (Nakagawa et al., 2014). Therefore, a capsule of $700 \mathrm{mg}$ was taken orally 3 times per day, (total 2,100 $\mathrm{mg}, 35 \mathrm{mg} / \mathrm{kg}-\mathrm{BW}$ ) (for a limited period of four weeks because of its high dosage) after consultation with experts.

\section{Exercise training program}

The exercise training program consisted of aerobic training of 30-min walking and weight training for increasing leg muscular strength. Aerobic exercise started at $15 \mathrm{~min}$ on the first week; thereafter, it increased by 5 min every week so that in the last week, walking time reached $30 \mathrm{~min}$. Weight training is composed of the movements for strengthening major muscles for the knee joint such as quadriceps femoris muscle, hamstrings, and triceps muscle of calf muscle (Han and Bang, 1994). Stretching, pressing down on the knee with a towel, tightening the towel, and gym ball squats carried out 8-10 times each, 2 sets total, and 3 times per week during the adaptation period of the first 2 weeks. During the improvement period ( 3 and 4 weeks), squats on a chair, kicks on a chair, and standing on heels on a chair were performed again 8-10 times each, 2 sets total, and 3 times per week.

\section{Statistical analysis}

The statistical analyses performed using IBM SPSS ver. 18.0

Table 2. The changes of body composition after treatment

\begin{tabular}{llccll}
\hline Variable & Group & Pre & Post & \multicolumn{2}{c}{ Sig } \\
\hline Weight $(\mathrm{kg})$ & $\mathrm{T}$ & $61.98 \pm 5.28$ & $61.91 \pm 4.93$ & Time & 0.601 \\
& $\mathrm{~T}+\mathrm{E}$ & $62.61 \pm 6.45$ & $62.45 \pm 6.56$ & Group & 0.806 \\
& & & & $\mathrm{~T} \times \mathrm{G}$ & 0.848 \\
Muscle mass $(\mathrm{kg})$ & $\mathrm{T}$ & $21.01 \pm 2.24$ & $21.68 \pm 1.31$ & Time & $0.049^{*}$ \\
& $\mathrm{~T}+\mathrm{E}$ & $21.84 \pm 2.42$ & $22.19 \pm 2.40$ & Group & 0.424 \\
& & & & $\mathrm{~T} \times \mathrm{G}$ & 0.531 \\
\%Fat (\%) & $\mathrm{T}$ & $37.69 \pm 5.19$ & $35.47 \pm 3.24$ & Time & $0.045^{*}$ \\
& $\mathrm{~T}+\mathrm{E}$ & $35.62 \pm 3.70$ & $34.45 \pm 3.60$ & Group & 0.275 \\
& & & & $\mathrm{~T} \times \mathrm{G}$ & 0.520 \\
$\begin{array}{l}\text { Body mass index } \\
\text { (kg/m })\end{array}$ & $\mathrm{T}$ & $25.55 \pm 2.11$ & $25.62 \pm 1.96$ & Time & 0.958 \\
& $\mathrm{~T}+\mathrm{E}$ & $25.31 \pm 2.67$ & $25.23 \pm 2.80$ & Group & 0.748 \\
& & & & $\mathrm{~T} \times \mathrm{G}$ & 0.463 \\
\hline
\end{tabular}

Values are presented as mean \pm standard deviation.

$\mathrm{T}$, Theracurmin intake; $T+E$, Theracurmin with exercise. ${ }^{*} P<0.05$.
(IBM Co., Armonk, NY, USA). The data expressed as average and the standard deviation for each group. A two-way analysis of variance with repeated measures performed to verify the effect of the time and treatment. The statistically significant level $(\alpha)$ for all analysis was 0.05 .

Table 3. The changes of pain score after treatment

\begin{tabular}{|c|c|c|c|c|c|}
\hline Variable & Group & Pre & Post & Si & \\
\hline \multirow[t]{3}{*}{ VAS (score) } & $\mathrm{T}$ & $4.42 \pm 1.16$ & $2.75 \pm 1.76$ & Time & $0.000^{* * *}$ \\
\hline & $\mathrm{T}+\mathrm{E}$ & $5.00 \pm 1.87$ & $3.08 \pm 2.36$ & Group & 0.474 \\
\hline & & & & $\mathrm{T} \times \mathrm{G}$ & 0.751 \\
\hline \multicolumn{6}{|l|}{ WOMAC (score) } \\
\hline \multirow[t]{3}{*}{ Pain } & $\mathrm{T}$ & $5.25 \pm 2.18$ & $3.17 \pm 2.41$ & Time & $0.000^{* * *}$ \\
\hline & $\mathrm{T}+\mathrm{E}$ & $6.38 \pm 3.43$ & $3.54 \pm 3.26$ & Group & 0.477 \\
\hline & & & & $T \times G$ & 0.455 \\
\hline \multirow[t]{3}{*}{ Joint stiffness } & T & $2.25 \pm 1.28$ & $2.25 \pm 1.48$ & Time & 0.239 \\
\hline & $\mathrm{T}+\mathrm{E}$ & $3.15 \pm 1.95$ & $34.45 \pm 1.72$ & Group & 0.437 \\
\hline & & & & $T \times G$ & 0.239 \\
\hline \multirow[t]{3}{*}{ Physical function } & $\mathrm{T}$ & $17.42 \pm 7.76$ & $13.67 \pm 9.49$ & Time & $0.002^{* *}$ \\
\hline & $\mathrm{T}+\mathrm{E}$ & $23.15 \pm 13.05$ & $14.54 \pm 10.87$ & Group & 0.400 \\
\hline & & & & $T \times G$ & 0.174 \\
\hline \multirow[t]{3}{*}{ Total } & $T$ & $24.92 \pm 10.21$ & $19.08 \pm 12.38$ & Time & $0.001^{* *}$ \\
\hline & $T+E$ & $32.69 \pm 17.44$ & $20.23 \pm 14.48$ & Group & 0.391 \\
\hline & & & & $T \times G$ & 0.163 \\
\hline
\end{tabular}

Values are presented as mean \pm standard deviation.

VAS, visual analogue scale; WOMAC, Western Ontario and MacMaster; T, Theracurmin intake; $T+E$, Theracurmin with exercise.

${ }^{* *} P<0.01 .{ }^{* *} P<0.001$.

Table 4. The changes of range of motion of knee after treatment

\begin{tabular}{|c|c|c|c|c|c|}
\hline \multirow{2}{*}{$\begin{array}{l}\text { Variable } \\
\text { More-pain site }\end{array}$} & \multirow[t]{2}{*}{ Group } & \multirow[t]{2}{*}{ Pre } & \multirow[t]{2}{*}{ Post } & \multicolumn{2}{|c|}{ Sig } \\
\hline & & & & & \\
\hline \multirow[t]{3}{*}{ Flextion $\left({ }^{\circ}\right)$} & $\mathrm{T}$ & $130.42 \pm 6.45$ & $135.58 \pm 8.46$ & Time & $0.000^{* * *}$ \\
\hline & $\mathrm{T}+\mathrm{E}$ & $127.00 \pm 8.79$ & $134.00 \pm 7.48$ & Group & 0.398 \\
\hline & & & & $T \times G$ & 0.458 \\
\hline \multirow[t]{3}{*}{ Extension $\left({ }^{\circ}\right)$} & $\mathrm{T}$ & $-11.08 \pm 2.50$ & $-9.50 \pm 1.88$ & Time & $0.001^{* *}$ \\
\hline & $\mathrm{T}+\mathrm{E}$ & $-10.85 \pm 3.58$ & $-8.69 \pm 3.40$ & Group & 0.629 \\
\hline & & & & $T \times G$ & 0.580 \\
\hline \multicolumn{6}{|l|}{ Less-pain site } \\
\hline \multirow[t]{3}{*}{ Flextion $\left({ }^{\circ}\right)$} & $\mathrm{T}$ & $131.50 \pm 5.99$ & $138.42 \pm 5.03$ & Time & $0.000^{* * *}$ \\
\hline & $\mathrm{T}+\mathrm{E}$ & $126.77 \pm 8.70$ & $135.15 \pm 11.01$ & Group & 0.104 \\
\hline & & & & $\mathrm{T} \times \mathrm{G}$ & 0.517 \\
\hline \multirow[t]{3}{*}{ Extension $\left({ }^{\circ}\right)$} & $\mathrm{T}$ & $-12.83 \pm 3.61$ & $-10.33 \pm 2.35$ & Time & $0.000^{* * *}$ \\
\hline & $\mathrm{T}+\mathrm{E}$ & $-11.54 \pm 2.15$ & $-8.15 \pm 2.91$ & Group & 0.086 \\
\hline & & & & $T \times G$ & 0.443 \\
\hline
\end{tabular}

Values are presented as mean \pm standard deviation.

$\mathrm{T}$, Theracurmin intake; $\mathrm{T}+\mathrm{E}$, Theracurmin with exercise.

${ }^{* *} P<0.01$. ${ }^{* *} P<0.001$. 


\section{RESULTS}

\section{The changes in body composition}

Table 2 shows the changes in body composition after 4 weeks of Theracurmin and exercise. BW and BMI were not significantly different. Muscle mass was significantly increased $(P<0.05)$, and the percent body fat was significantly decreased $(P<0.05)$ after treatment. There was no correlation between time and group.

\section{The changes in pain score}

Table 3 shows the changes in pain score after 4 weeks of Theracurmin and exercise. The VAS was significantly decreased after 4 weeks $(P<0.001)$. WOMAC score was significantly decreased in pain $(P<0.001)$, physical function difficulties $(P<0.01)$, and total score $(P<0.01)$. There was no correlation between time and group.

\section{The changes in ROM of the knee}

Table 4 shows the changes in ROM of the knee after 4 weeks of
Table 6. The changes of walking after treatment

\begin{tabular}{|c|c|c|c|c|c|}
\hline \multirow{2}{*}{$\begin{array}{l}\text { Variable } \\
10-M \text { walking }\end{array}$} & \multirow[t]{2}{*}{ Group } & \multirow[t]{2}{*}{ Pre } & \multirow[t]{2}{*}{ Post } & \multicolumn{2}{|c|}{ Sig } \\
\hline & & & & & \\
\hline \multirow[t]{3}{*}{ Speed (sec) } & $\mathrm{T}$ & $7.42 \pm 0.74$ & $6.72 \pm 0.76$ & Time & $0.000^{* * *}$ \\
\hline & $\mathrm{T}+\mathrm{E}$ & $7.04 \pm 0.75$ & $6.509 \pm 0.80$ & Group & 0.309 \\
\hline & & & & $\mathrm{T} \times \mathrm{G}$ & 0.478 \\
\hline \multirow[t]{3}{*}{ Gravity (N) } & $\mathrm{T}$ & $618.17 \pm 50.81$ & $610.50 \pm 61.58$ & Time & $0.008^{* *}$ \\
\hline & $\mathrm{T}+\mathrm{E}$ & $628.77 \pm 67.60$ & $602.38 \pm 65.13$ & Group & 0.959 \\
\hline & & & & $T \times G$ & 0.126 \\
\hline \multicolumn{6}{|c|}{ Stair ascending \& descending } \\
\hline \multirow[t]{3}{*}{ Ascending (sec) } & $\mathrm{T}$ & $4.71 \pm 1.05$ & $4.63 \pm 0.83$ & Time & $0.000^{* * *}$ \\
\hline & $\mathrm{T}+\mathrm{E}$ & $4.13 \pm 0.72$ & $4.14 \pm 0.72$ & Group & 0.909 \\
\hline & & & & $T \times G$ & 0.697 \\
\hline \multirow[t]{3}{*}{ Descending (sec) } & $\mathrm{T}$ & $4.32 \pm 0.88$ & $6.32 \pm 9.37$ & Time & 0.631 \\
\hline & $\mathrm{T}+\mathrm{E}$ & $4.35 \pm 1.33$ & $3.65 \pm 0.67$ & Group & 0.326 \\
\hline & & & & $T \times G$ & 0.321 \\
\hline
\end{tabular}

Values are presented as mean \pm standard deviation.

$\mathrm{T}$, Theracurmin intake; $\mathrm{T}+\mathrm{E}$, Theracurmin with exercise.

${ }^{* *} P<0.01 .{ }^{* *} P<0.001$

Table 5. The changes of balance after treatment

\begin{tabular}{|c|c|c|c|c|c|}
\hline \multirow{2}{*}{$\begin{array}{l}\text { Variable } \\
\text { More-pain site }\end{array}$} & \multirow[t]{2}{*}{ Group } & \multirow[t]{2}{*}{ Pre } & \multirow[t]{2}{*}{ Post } & \multicolumn{2}{|c|}{ Sig } \\
\hline & & & & & \\
\hline \multirow[t]{3}{*}{ One-leg with open eyes (sec) } & $\mathrm{T}$ & $53.47 \pm 14.98$ & $54.38 \pm 13.13$ & Time & 0.470 \\
\hline & $\mathrm{T}+\mathrm{E}$ & $53.21 \pm 14.89$ & $57.71 \pm 8.27$ & Group & 0.684 \\
\hline & & & & $T \times G$ & 0.630 \\
\hline \multirow[t]{3}{*}{ One-leg with closed eyes (sec) } & $\mathrm{T}$ & $8.37 \pm 7.47$ & $17.85 \pm 16.79$ & Time & 0.139 \\
\hline & $\mathrm{T}+\mathrm{E}$ & $11.73 \pm 15.53$ & $14.73 \pm 19.22$ & Group & 0.979 \\
\hline & & & & $T \times G$ & 0.434 \\
\hline \multirow[t]{3}{*}{ COP with open eyes (mm) } & $\mathrm{T}$ & $2,113.49 \pm 295.29$ & $1,392.79 \pm 423.50$ & Time & $0.006^{* *}$ \\
\hline & $\mathrm{T}+\mathrm{E}$ & $1,766.78 \pm 826.30$ & $1,557.48 \pm 736.27$ & Group & 0.666 \\
\hline & & & & $\mathrm{T} \times \mathrm{G}$ & 0.106 \\
\hline \multirow[t]{3}{*}{ COP with closed eyes (mm) } & $\mathrm{T}$ & $1,483.45 \pm 1,750.88$ & $958.32 \pm 1,409.48$ & Time & $0.002^{* *}$ \\
\hline & $\mathrm{T}+\mathrm{E}$ & $694.34 \pm 855.78$ & $467.68 \pm 441.16$ & Group & 0.186 \\
\hline & & & & $T \times G$ & 0.181 \\
\hline \multicolumn{6}{|l|}{ Less-pain site } \\
\hline \multirow[t]{3}{*}{ One-leg with open eyes (sec) } & $\mathrm{T}$ & $55.89 \pm 12.46$ & $54.78 \pm 11.11$ & Time & 0.447 \\
\hline & $\mathrm{T}+\mathrm{E}$ & $52.59 \pm 18.44$ & $58.39 \pm 5.79$ & Group & 0.970 \\
\hline & & & & $T \times G$ & 0.265 \\
\hline \multirow[t]{3}{*}{ One-leg with closed eyes (sec) } & $\mathrm{T}$ & $13.32 \pm 17.02$ & $10.72 \pm 9.28$ & Time & 0.912 \\
\hline & $\mathrm{T}+\mathrm{E}$ & $13.32 \pm 15.91$ & $17.06 \pm 19.06$ & Group & 0.508 \\
\hline & & & & $T \times G$ & 0.458 \\
\hline \multirow[t]{3}{*}{ COP with open eyes (mm) } & $\mathrm{T}$ & $1,973.89 \pm 399.00$ & $1,674.17 \pm 476.55$ & Time & 0.090 \\
\hline & $\mathrm{T}+\mathrm{E}$ & $1,754.58 \pm 722.93$ & $1,583.29 \pm 642.03$ & Group & 0.423 \\
\hline & & & & $\mathrm{T} \times \mathrm{G}$ & 0.635 \\
\hline \multirow[t]{3}{*}{ COP with closed eyes (mm) } & $\mathrm{T}$ & $1,166.72 \pm 1,043.09$ & $397.59 \pm 220.48$ & Time & $0.002^{* *}$ \\
\hline & $\mathrm{T}+\mathrm{E}$ & $952.79 \pm 1,011.25$ & $372.33 \pm 378.48$ & Group & 0.608 \\
\hline & & & & $T \times G$ & 0.639 \\
\hline
\end{tabular}

Values are presented as mean \pm standard deviation.

$\mathrm{COP}$, centers of pressure; $T$, Theracurmin intake; $T+E$, Theracurmin with exercise.

${ }^{* *} P<0.01$. 
Theracurmin and exercise. The angle of flexion and extension in more-pain site and less-pain site was decreased after 4 weeks $(P<$ $0.001)$, however there was no correlation between time and group.

\section{The changes in balance}

Table 5 shows the changes in balance after 4 weeks of Theracurmin and exercise. The time of one leg standing with and without eyes closed was not significantly different in more-pain site, COP with closed eye was decreased after 4 weeks $(P<0.01)$. COP with closed eye in less-pain site was significantly decreased after 4 weeks $(P<0.01)$.

\section{The changes in walking}

Table 6 shows the changes in walking after 4 weeks of Theracurmin and exercise. $10-\mathrm{m}$ walking speed $(P<0.001)$, gravity $(P<0.01)$, and stair ascending speed $(P<0.001)$ were significantly decreased after treatment.

\section{The changes in isokinetic strength}

Table 7 shows the changes in isokinetic strength after 4 weeks of Theracurmin and exercise. The muscle strength of more-pain site was significantly increased for peak torque and total work for both flexion and extension $(P<0.01)$. Total work in extension shows correlation between time and group $(P=0.057)$. The muscle strength

Table 7. The changes of isokinetic strength after treatment

\begin{tabular}{|c|c|c|c|c|c|}
\hline Variable & Group & Pre & Post & \multicolumn{2}{|c|}{ Sig } \\
\hline \multicolumn{6}{|l|}{ More-pain site } \\
\hline \multicolumn{6}{|l|}{ Flexion } \\
\hline \multirow[t]{3}{*}{ Peak torque $(\mathrm{Nm})$} & $\mathrm{T}$ & $29.58 \pm 8.12$ & $37.33 \pm 9.84$ & Time & $0.000^{* * *}$ \\
\hline & $\mathrm{T}+\mathrm{E}$ & $30.75 \pm 14.51$ & $40.50 \pm 17.42$ & Group & 0.666 \\
\hline & & & & $\mathrm{T} \times \mathrm{G}$ & 0.608 \\
\hline \multirow[t]{3}{*}{ Work (Watt) } & $\mathrm{T}$ & $156.67 \pm 47.21$ & $184.08 \pm 53.25$ & Time & $0.001^{* *}$ \\
\hline & $\mathrm{T}+\mathrm{E}$ & $156.67 \pm 85.26$ & $200.67 \pm 95.29$ & Group & 0.933 \\
\hline & & & & $\mathrm{T} \times \mathrm{G}$ & 0.214 \\
\hline \multicolumn{6}{|l|}{ Extension } \\
\hline \multirow[t]{3}{*}{ Peak torque (Nm) } & $\mathrm{T}$ & $68.75 \pm 14.96$ & $75.42 \pm 14.30$ & Time & $0.001^{* *}$ \\
\hline & $\mathrm{T}+\mathrm{E}$ & $70.25 \pm 22.49$ & $75.42 \pm 23.68$ & Group & 0.843 \\
\hline & & & & $\mathrm{T} \times \mathrm{G}$ & 0.980 \\
\hline \multirow[t]{3}{*}{ Work (Watt) } & $\mathrm{T}$ & $361.33 \pm 84.89$ & $375.50 \pm 69.52$ & Time & $0.005^{* *}$ \\
\hline & $\mathrm{T}+\mathrm{E}$ & $349.25 \pm 151.45$ & $415.67 \pm 136.77$ & Group & 0.760 \\
\hline & & & & $T \times G$ & $0.057^{\dagger}$ \\
\hline \multicolumn{6}{|l|}{ Less-pain site } \\
\hline \multicolumn{6}{|l|}{ Flexion } \\
\hline \multirow[t]{3}{*}{ Peak torque (Nm) } & $\mathrm{T}$ & $28.83 \pm 7.22$ & $35.67 \pm 9.70$ & Time & $0.000^{* * *}$ \\
\hline & $\mathrm{T}+\mathrm{E}$ & $28.83 \pm 17.22$ & $37.92 \pm 19.51$ & Group & 0.651 \\
\hline & & & & $T \times G$ & 0.773 \\
\hline \multirow[t]{3}{*}{ Work (Watt) } & $\mathrm{T}$ & $152.92 \pm 42.17$ & $178.00 \pm 46.75$ & Time & $0.001^{* *}$ \\
\hline & $\mathrm{T}+\mathrm{E}$ & $162.75 \pm 100.26$ & $196.25 \pm 105.89$ & Group & 0.660 \\
\hline & & & & $\mathrm{T} \times \mathrm{G}$ & 0.594 \\
\hline \multicolumn{6}{|l|}{ Extension } \\
\hline \multirow[t]{3}{*}{ Peak torque (Nm) } & $\mathrm{T}$ & $75.00 \pm 17.37$ & $81.25 \pm 18.42$ & Time & $0.000^{* * *}$ \\
\hline & $\mathrm{T}+\mathrm{E}$ & $90.08 \pm 82.76$ & $106.92 \pm 99.05$ & Group & 0.454 \\
\hline & & & & $\mathrm{T} \times \mathrm{G}$ & 0.075 \\
\hline \multirow[t]{3}{*}{ Work (Watt) } & $\mathrm{T}$ & $388.92 \pm 88.20$ & $384.33 \pm 85.06$ & Time & 0.102 \\
\hline & $\mathrm{T}+\mathrm{E}$ & $347.33 \pm 152.39$ & $409.67 \pm 120.23$ & Group & 0.854 \\
\hline & & & & $\mathrm{T} \times \mathrm{G}$ & $0.061^{\dagger}$ \\
\hline
\end{tabular}

Values are presented as mean \pm standard deviation.

$T$, Theracurmin intake; $T+E$, Theracurmin with exercise.

${ }^{* *} P<0.01 .{ }^{* * *} P<0.001$. ${ }^{\dagger}$ Trend for significant. 
of less-pain site was significantly increased for peak torque $(P<0.001)$, total work in flexion $(P<0.01)$, and peak torque in extension $(P<$ 0.001). The total work in extension shows correlation between time and group $(P=0.061)$.

\section{DISCUSSION}

This study was investigated the Theracurmin intake in conjunction with exercise effects on pain, muscular function and daily living functions in osteoarthritis patients. The results showed that both $\mathrm{T}$ and $\mathrm{T}+\mathrm{E}$ groups showed improvements on all the investigated elements, and the difference between groups only observed in the total work amount during extension of the muscle.

The major symptoms for osteoarthritis patients are pain, and joint stiffness that decreases movement caused by limits the patient's capacity for daily activities (Altman, 1991). Therefore, the priority for the symptom management of osteoarthritis patients must be pain control via drug treatment or nondrug treatment (Bruyère et al., 2014; Fernandes et al., 2013; McAlindon et al., 2014). However, because current long-term drug treatments can have side effects, most studies conducted on disease modifying agents. Curcumin is one such disease-modifying agent and known to have an anti-inflammatory property that suppresses prostaglandin synthesis by affecting cyclooxygenase, an enzyme important for converting arachidonic acid to prostaglandins (Rao, 2007). It has been reported that curcumin is a catabolic mediator that inhibits inflammation by suppressing nuclear factor-kappa B activation, a key event in chronic inflammatory response (Buhrmann et al., 2010). In this study, pain score (VAS scale) as well as pain, function, and total scores in the WOMAC score were decreased in both, the $\mathrm{T}$ and $\mathrm{T}+\mathrm{E}$ groups with a 4-week intake of Theracurmin, which has a 27 -fold increased physiologic activity compared to curcumin. Although there was no significant improvement shown in joint stiffness in WOMAC score, the range of motion of the knee joint improved in both flexion and extension.

It proposed that these positive changes were the result of the effect of Theracurmin intake that reduced pain and discomfort from osteoarthritis. Furthermore, aerobic and weight exercise is one of the most strongly recommended treatments among the nondrug treatment options for osteoarthritis (Hochberg et al., 2012), and has been shown to be effective in decreasing discomfort due to the pain of osteoarthritis (Juhl et al., 2014). Therefore, use of both Theracurmin and exercise can be propose to be effective in decreasing pain and enhancing joint function.

According to previous studies, pain due to osteoarthritis and joint movement disorders seem to cause reduction in muscular strength of quadriceps femoris muscle as well as loss of sensation and proprioception (Hassan et al., 2001; Wegener et al., 1997). Balance is a collaborative response of maintaining sensory information transmitted from vestibular organs and visual and somato sensory organs through neurologic and muscular response from the central nerve system (Koceja et al., 1999), and reduction in proprioception for osteoarthritis patients can limit physical activities such as walking or balancing (van der Esch et al., 2007). As a result of Theracurmin intake with and without exercise for 4 weeks, there was no increase in the time for standing on one foot, but the degree of shaking in the center of gravity while standing on one foot both, with eyes open and closed had significantly improved. In addition, the performance in the 10-m walking test and while walking up the stairs improved. This suggests that the Theracurmin and exercise treatments helped decrease shaking of the patient's center of gravity by reducing pain. In addition, the reduced pain effect to increase the daily steps during the 4 weeks of treatment, thereby enhancing the capabilities of the $10-\mathrm{m}$ walk and walking up the stairs. However, improvements in movement and walking ability were equivalent in both groups of Theracurmin only and Theracurmin with exercise. This was likely because the treatment period was relatively short to reveal the effect of exercise, and because both groups showed increased daily steps.

It has been reported that pain in the knee joint also affects muscular strength. Messier et al. (2002) reported that the muscular strength of the quadriceps femoris muscle is lower in a group of patients with chronic pain than in a group of patients without chronic pain. It has also been reported that when pain in the knee joint is decreased using local anesthetics quadriceps femoris muscular strength is significantly increased (Hassan et al., 2002). Kim et al. (2013) reported that a significant difference was seen when comparing more pain sites and less pain sites for knee joint extension but not for knee joint flexion. In this study, in terms of muscular strength, both, the peak torque and total work improved in flexion and extension; the $\mathrm{T}+\mathrm{E}$ group displayed more improvement than the $\mathrm{T}$ group during extension, showing correlation between the group and the treatment. On lesser pain sites, both, the peak torque and total work increased during flexion, but only the peak torque increased during extension, and the total work increased in only the $\mathrm{T}+\mathrm{E}$ group, with group treatment correlation as demonstrated in the previous studies.

Pain in the knee joint causes reflex muscle inhibition that makes pushing the isokinetic instrument more difficult during the muscular strength measurement, decreases the activity of the quadri- 
ceps femoris muscle, and therefore weakens the extension muscle (Sahin et al., 2008). Therefore, we propose that pain reduction of the knee joint from Theracurmin intake must have caused an increase in muscular strength. In addition, it has been reported that aerobic exercise and weight training for the quadriceps femoris muscle are effective in decreasing pain and movement disorder of osteoarthritis patients (Juhl et al., 2014). We propose that $\mathrm{T}+\mathrm{E}$ exercise group showed more improvements than $\mathrm{T}$ group caused by aerobic exercise and weight training is strengthen the quadriceps femoris, hamstring muscle, and triceps muscle of calf.

In conclusion, the 4-week intake of Theracurmin with and without exercise appeared to be effective in reducing the pain and enhancing muscular and balancing function. Although no difference observed between the two groups except for muscular strength, the effects of exercise depend on its intensity and duration. In addition, as reported previously, the longer the exercise period, higher the improvement (Fernandes et al., 2013). Therefore, increasing the exercise period duration would expected to further alleviate the symptoms of osteoarthritis compared to Theracurmin intake without exercise. Therefore, Theracurmin intake for early symptoms and additional exercise as symptoms alleviate might be an effective way of delaying and managing osteoarthritis, and additional studies investigating the effects of Theracurmin and exercise on osteoarthritis could be beneficial.

\section{CONFLICT OF INTEREST}

No potential conflict of interest relevant to this article was reported.

\section{REFERENCES}

Aigner T, Sachse A, Gebhard PM, Roach HI. Osteoarthritis: pathobiology-targets and ways for therapeutic intervention. Adv Drug Deliv Rev 2006;58:128-149.

Akazawa N, Choi Y, Miyaki A, Tanabe Y, Sugawara J, Ajisaka R, Maeda S. Curcumin ingestion and exercise training improve vascular endothelial function in postmenopausal women. Nutr Res 2012;32:795-799.

Altman RD. Criteria for classification of clinical osteoarthritis. J Rheumatol Suppl 1991;27:10-12.

Anand P, Kunnumakkara AB, Newman RA, Aggarwal BB. Bioavailability of curcumin: problems and promises. Mol Pharm 2007;4:807-818.

Bellamy N. Validation study of WOMAC: a health status instrument for measuring clinically-important patient-relevant outcomes following total hip or knee arthroplasty in osteoarthritis. J Orthop Rheumatol
1988;1:95-108.

Bruyère $\mathrm{O}$, Cooper C, Pelletier JP, Branco J, Luisa Brandi M, Guillemin F, Hochberg MC, Kanis JA, Kvien TK, Martel-Pelletier J, Rizzoli R, Silverman S, Reginster JY. An algorithm recommendation for the management of knee osteoarthritis in Europe and internationally: a report from a task force of the European Society for Clinical and Economic Aspects of Osteoporosis and Osteoarthritis (ESCEO). Semin Arthritis Rheum 2014;44:253-263.

Buhrmann C, Mobasheri A, Matis U, Shakibaei M. Curcumin mediated suppression of nuclear factor- $\kappa \mathrm{B}$ promotes chondrogenic differentiation of mesenchymal stem cells in a high-density co-culture microenvironment. Arthritis Res Ther 2010;12:R127.

Chemoprevention Branch and Agent Development Committee. Clinical development plan: curcumin. J Cell Biochem Suppl 1996;26:72-85.

Cross M, Smith E, Hoy D, Nolte S, Ackerman I, Fransen M, Bridgett L, Williams S, Guillemin F, Hill CL, Laslett LL, Jones G, Cicuttini F, Osborne R, Vos T, Buchbinder R, Woolf A, March L. The global burden of hip and knee osteoarthritis: estimates from the global burden of disease 2010 study. Ann Rheum Dis 2014;73:1323-1330.

Davies CM, Guilak F, Weinberg JB, Fermor B. Reactive nitrogen and oxygen species in interleukin-1-mediated DNA damage associated with osteoarthritis. Osteoarthritis Cartilage 2008;16:624-630.

Felson DT, Lawrence RC, Hochberg MC, McAlindon T, Dieppe PA, Minor MA, Blair SN, Berman BM, Fries JF, Weinberger M, Lorig KR, Jacobs JJ, Goldberg V. Osteoarthritis: new insights. Part 2: treatment approaches. Ann Intern Med 2000;133:726-737.

Fernandes L, Hagen KB, Bijlsma JW, Andreassen O, Christensen P, Conaghan PG, Doherty M, Geenen R, Hammond A, Kjeken I, Lohmander LS, Lund H, Mallen CD, Nava T, Oliver S, Pavelka K, Pitsillidou I, da Silva JA, de la Torre J, Zanoli G, Vliet Vlieland TP; European League Against Rheumatism (EULAR). EULAR recommendations for the non-pharmacological core management of hip and knee osteoarthritis. Ann Rheum Dis 2013;72:1125-1135.

Franklin PD, Li W, Ayers DC. The Chitranjan Ranawat Award: functional outcome after total knee replacement varies with patient attributes. Clin Orthop Relat Res 2008;466:2597-2604.

Goel A, Kunnumakkara AB, Aggarwal BB. Curcumin as "Curecumin": from kitchen to clinic. Biochem Pharmacol 2008;75:787-809.

Guccione AA, Felson DT, Anderson JJ, Anthony JM, Zhang Y, Wilson PW, Kelly-Hayes M, Wolf PA, Kreger BE, Kannel WB. The effects of specific medical conditions on the functional limitations of elders in the Framingham Study. Am J Public Health 1994;84:351-358.

Gupta SC, Patchva S, Koh W, Aggarwal BB. Discovery of curcumin, a component of golden spice, and its miraculous biological activities. Clin Exp Pharmacol Physiol 2012;39:283-299. 
Han TR, Bang MS. Isokinetic tests in patients with degenerative joint disease of knee. Ann Rehabil Med 1994;18:328-332.

Hassan BS, Doherty SA, Mockett S, Doherty M. Effect of pain reduction on postural sway, proprioception, and quadriceps strength in subjects with knee osteoarthritis. Ann Rheum Dis 2002;61:422-428.

Hassan BS, Mockett S, Doherty M. Static postural sway, proprioception, and maximal voluntary quadriceps contraction in patients with knee osteoarthritis and normal control subjects. Ann Rheum Dis 2001;60: 612-618.

Henrotin Y, Sanchez C, Reginster JY. The inhibition of metalloproteinases to treat osteoarthritis: reality and new perspectives. Expert Opin Ther Pat 2002;12:29-43.

Hochberg MC, Altman RD, April KT, Benkhalti M, Guyatt G, McGowan J, Towheed T, Welch V, Wells G, Tugwell P; American College of Rheumatology. American College of Rheumatology 2012 recommendations for the use of nonpharmacologic and pharmacologic therapies in osteoarthritis of the hand, hip, and knee. Arthritis Care Res (Hoboken) 2012;64:465-474.

Hong UJ. Effects 8 weeks exercise programs on joint function, muscle strength, flexibility and balance on aged women [master's thesis]. Daejeon: Konyang University; 2007.

Jordan KM, Arden NK, Doherty M, Bannwarth B, Bijlsma JW, Dieppe P, Gunther K, Hauselmann H, Herrero-Beaumont G, Kaklamanis P, Lohmander S, Leeb B, Lequesne M, Mazieres B, Martin-Mola E, Pavelka K, Pendleton A, Punzi L, Serni U, Swoboda B, Verbruggen G, Zimmerman-Gorska I, Dougados M; Standing Committee for International Clinical Studies Including Therapeutic Trials ESCISIT. EULAR Recommendations 2003: an evidence based approach to the management of knee osteoarthritis: Report of a Task Force of the Standing Committee for International Clinical Studies Including Therapeutic Trials (ESCISIT). Ann Rheum Dis 2003;62:1145-1155.

Juhl C, Christensen R, Roos EM, Zhang W, Lund H. Impact of exercise type and dose on pain and disability in knee osteoarthritis: a systematic review and meta-regression analysis of randomized controlled trials. Arthritis Rheumatol 2014;66:622-636.

Kim JH, Hwang JH, Ko MJ, Min KB, Park WH, Kwon TK. The effects of knee pain on the quadriceps strength, proprioception and balance in patients with knee osteoarthritis. Korean J Sports Med 2013;31:1-6.

Koceja DM, Allway D, Earles DR. Age differences in postural sway during volitional head movement. Arch Phys Med Rehabil 1999;80:1537-1541.

Mathy-Hartert M, Jacquemond-Collet I, Priem F, Sanchez C, Lambert C, Henrotin Y. Curcumin inhibits pro-inflammatory mediators and metalloproteinase-3 production by chondrocytes. Inflamm Res 2009;58:899-
908.

McAlindon TE, Bannuru RR, Sullivan MC, Arden NK, Berenbaum F, Bierma-Zeinstra SM, Hawker GA, Henrotin Y, Hunter DJ, Kawaguchi H, Kwoh K, Lohmander S, Rannou F, Roos EM, Underwood M. OARSI guidelines for the non-surgical management of knee osteoarthritis. Osteoarthritis Cartilage 2014;22:363-388.

Messier SP, Glasser JL, Ettinger WH Jr, Craven TE, Miller ME. Declines in strength and balance in older adults with chronic knee pain: a 30-month longitudinal, observational study. Arthritis Rheum 2002;47:141-148.

Mobasheri A, Henrotin Y, Biesalski HK, Shakibaei M. Scientific evidence and rationale for the development of curcumin and resveratrol as nutraceutricals for joint health. Int J Mol Sci 2012;13:4202-4232.

Nakagawa Y, Mukai S, Yamada S, Matsuoka M, Tarumi E, Hashimoto T, Tamura C, Imaizumi A, Nishihira J, Nakamura T. Short-term effects of highly-bioavailable curcumin for treating knee osteoarthritis: a randomized, double-blind, placebo-controlled prospective study. J Orthop Sci 2014;19:933-939.

Rao CV. Regulation of COX and LOX by curcumin. Adv Exp Med Biol 2007;595:213-226.

Roddy E, Zhang W, Doherty M. Aerobic walking or strengthening exercise for osteoarthritis of the knee? A systematic review. Ann Rheum Dis 2005;64:544-548.

Sahin N, Baskent A, Cakmak A, Salli A, Ugurlu H, Berker E. Evaluation of knee proprioception and effects of proprioception exercise in patients with benign joint hypermobility syndrome. Rheumatol Int 2008; 28:995-1000.

Shoba G, Joy D, Joseph T, Majeed M, Rajendran R, Srinivas PS. Influence of piperine on the pharmacokinetics of curcumin in animals and human volunteers. Planta Med 1998;64:353-356.

van der Esch M, Steultjens M, Harlaar J, Knol D, Lems W, Dekker J. Joint proprioception, muscle strength, and functional ability in patients with osteoarthritis of the knee. Arthritis Rheum 2007;57:787-793.

Vogel HA, Pelletier J. Curcumin-biological and medicinal properties. J Pharma 1815;2:50.

Wegener L, Kisner C, Nichols D. Static and dynamic balance responses in persons with bilateral knee osteoarthritis. J Orthop Sports Phys Ther 1997;25:13-18.

Wongcharoen W, Phrommintikul A. The protective role of curcumin in cardiovascular diseases. Int J Cardiol 2009;133:145-151.

Yi SJ, Lee HJ, Woo YK. Validity and reliability of the Western Ontario and McMaster Universities Osteoarthritis Index (WOMAC)-VA3.0 in hip and knee osteoarthritis patients. Phys Ther Korea 2008;15:20-29. 